Fourth International Conference on Sustainable Construction Materials and Technologies

http://www.claisse.info/Proceedings.htm

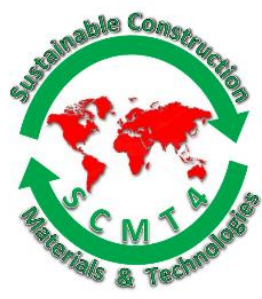

SCMT4

Las Vegas, USA, August 7-11, 2016

\title{
Construction and Demolition Waste as Raw Materials for Sustainable Cements
}

\author{
M. Marroccoli*1a , A. Telesca ${ }^{1 \mathrm{~b}}$, N. Ibris ${ }^{1 \mathrm{c}}$ and T. R. Naik ${ }^{2}$ \\ ${ }^{1}$ School of Engineering, Università degli Studi della Basilicata, ITALY. \\ ${ }^{1 a}$ Email: <milena.marroccoli@unibas.it>, ${ }^{1 b}$ Email: < antonio.telesca@unibas.it>, ${ }^{1 c}$ Email: \\ <neluta.ibris@unibas.it>. \\ ${ }^{2}$ Department of Civil Engineering and Mechanics, University of Wisconsin, USA. \\ Email: 〈tarun@uwm.edu>
}

\begin{abstract}
In 2014 about four billion tonnes of cement were produced [CEMBUREAU, 2014]. The use of industrial by-products, as a source of raw materials in the manufacture of portland and blended cements, is a research theme of significant relevance to the construction industry. Such industrial by products can be employed as constituents of the final product or components of the raw feed in a cement kiln. Due to their hydraulic and/or pozzolanic activity, industrial by-products are utilized worldwide. Such by-products also increase durability and reduce costs for producing blended cements.
\end{abstract}

The use of such by-products as raw mixture component for the cement production has received comparatively little attention by researchers and engineers. There is currently an increasing interest towards searching for new categories of by-products, which would be able to provide reactive calcium, silicon, aluminum, and/or iron oxides, for portland cement clinker manufacture. In this regard, construction and demolition waste $(\mathrm{C} \& \mathrm{DW})$ is worthy of consideration because, when obtained from a properly selective demolition process, they could be employed as alternative raw material for portland clinker production.

The present study deals with the use of two different kinds of C\&DW, namely concrete waste (CW) and masonry waste (MW). In this study, C\&DW is proposed to be employed as partial or total substitute for limestone and clay, respectively, in the portland clinker generating raw mixture. Four ternary mixtures containing limestone, as well as $\mathrm{CW}$ and $\mathrm{MW}$, were subjected to laboratory tests in order to evaluate the clinker raw mixture produced and the performance of the related portland cement. A binary mixture, composed of limestone and clay, was used as a reference. All of these different cements displayed similar hydration behavior. Detailed results are presented and discussed.

\section{INTRODUCTION}

Huge and growing amounts of construction and demolition waste (C\&DW) are generated in Europe each year. In 2012 the estimated production of C\&DW in the EU-28 (the 28 countries comprising of EU) was 
about 820 million tons, representing about the $33 \%$ of the total generated waste[Eurostat 2012]. In the past few years, due to the increasing attention toward the environmental protection as well as the progressively reducing landfill capacity, $\mathrm{C} \& \mathrm{DW}$ has been receiving more and more importance in the European Union waste strategy. The waste framework directive 2008/98/EC of the European Parliament establishes that a minimum recycling rate of $70 \%$ for C\&DW should be achieved by 2020 in the EU countries. Nowadays the C\&DW recycling among EU-28 members ranges from 10 to $90 \%$ (47\% on the average).

C\&DW products include bricks, concrete, ceramics, glass, asphalt, tiles, gypsum, wallboard, wood, metals, different types of plastics and so on [Dahlbo et al. 2015]. In order to maximize the reuse of this not homogeneous products, changes in the management of construction and demolition activities have to be taken into account. Therefore, selective demolition [Silva et al. 2014], namely the systematic disassembly of buildings, allow the use of separated and uncontaminated materials for future recycling applications.

Three main types of recycled aggregates (RA) arise from C\&DW after being crushed and screened in recycling plants. These materials are crushed concrete, crushed masonry and mixed demolition debris [Vieira and Pereira 2015]. The use of RA, as replacement for natural aggregates in construction applications, is undoubtedly one of the most efficient approaches for recycling materials from C\&DW. The practice of using RA is widely practiced in Belgium, Denmark, and Netherlands (where more than $80 \%$ of natural aggregates are saved) [Corinaldesi and Moriconi 2009]. Whereas this practice is less common in Southern Europe [Gastaldi et al. 2015].

The quality of the environment is negatively influenced by cement manufacture. In fact, huge amounts of natural resources are consumed and large quantities of pollutants are generated, including also carbon dioxide, which is responsible for the greenhouse effect, originating from both fossil fuel combustion and limestone thermal decomposition occurring during cement manufacture [Bernardo et al. 2007].

On the other hand, the cement industry is able to absorb, as alternative fuels or raw materials, solid residues and by-products derived from other activities, thus giving a significant contribution to a sustainable development. The waste utilization as an energy source is favored by the peculiar characteristics of the processes occurring in the cement kiln: the burnt product (clinker) has a strong absorption capacity towards other substances due to its suitable chemical properties and the high kiln temperatures, $1450^{\circ}-1500^{\circ} \mathrm{C}$ [Kääntee et al. 2004; MacGregor 1994; Mokrzycki and Bochenczyk 2003; Trezza and Scian 2000].

The use of industrial by-products, as a source of raw materials in the manufacture of portland and blended cements, is a research theme of significant relevance to the construction industry. Such industrial byproducts can be employed as constituents of the final product or components of the raw feed in a cement kiln. Regarding the use of these by-products as a blended cement materials, such as coal ash, rice-husk ash, biomass ash, blast-furnace slag, silica fume, and other similar materials, due to their hydraulic and/or pozzolanic activity, are utilized worldwide [Bijen 1996; Sano et al. 2002; Mahmud et al. 2004; Ramezanianpour and Pourkhorshidi 2004; Gartner and Hirao 2015]. Use of such blended cements increase durability and reduce cost of the construction. The use of such by-products as raw mixture component for the cement kiln has received comparatively little attention by researchers and engineers. There is currently an increasing interest towards searching for new categories of by-products, which would be able to provide reactive calcium, silicon, aluminum, and/or iron oxides, for portland cement clinker manufacture [Marroccoli et al. 2010; Telesca et al. 2014; Schoon et al. 2015; Telesca et al. 2015]. In this regard, C\&DW is worthy of consideration because, when obtained from a properly selective demolition process, they could be employed as alternative raw material for portland clinker production. 
The present study deals with the use of two different kinds of C\&DW, namely concrete $(\mathrm{CW})$ and masonry waste (MW), as partial or total substitutes for limestone and clay, respectively, in the portland clinker generating raw mixture.

\section{EXPERIMENTAL INVESTIGATIONS}

Materials. Limestone (L) and clay (C) were supplied by a local cement factory located in the Potenza's area. Two CW and two MW samples (CW1, CW2, MW1 and MW2), coming from a selective demolition process, were obtained from a local recycling plant.

Limestone, together with CW and MW samples, was further crushed by means of a jaw crusher and then pulverized in a planetary mill until it passed a $90 \mu \mathrm{m}$ sieve. Clay sample, after an overnight drying in a laboratory oven a $105^{\circ} \mathrm{C}$, was milled in order to obtain particles size lower than $90 \mu \mathrm{m}$.

The chemical and mineralogical composition of the natural raw materials and C\&DW was determined by X-ray fluorescence (XRF) and X-ray diffraction (XRD) analyses, using a Bruker-Explorer S4 instrument and a Bruker D2 Phaser diffractometer (scan velocity $0.02^{\circ} 2 \theta / \mathrm{s}$ ), respectively.

Table 1 shows the chemical composition of natural raw materials and C\&DW, in terms of major oxides and loss on ignition (LOI) values.

$\mathrm{CaO}$ was the main constituent of $\mathrm{L}$, while $\mathrm{SiO}_{2}$ (principal oxide) together with $\mathrm{Al}_{2} \mathrm{O}_{3}$ and $\mathrm{CaO}$ (secondary components) were the main detected oxides of $\mathrm{C}, \mathrm{MW} 1$, and MW2, With regard to L, CW1 and CW2 were lower in $\mathrm{CaO}$ and higher in $\mathrm{SiO}_{2}$.

Table 1. Chemical composition of natural materials and C\&DW by-products, mass \%

\begin{tabular}{|c|c|c|c|c|c|c|}
\hline & $\mathrm{L}$ & $\mathrm{C}$ & $\mathrm{CW} 1$ & $\mathrm{CW} 2$ & MW1 & MW2 \\
\hline $\mathrm{CaO}$ & 54.60 & 8.93 & 37.02 & 39.92 & 15.90 & 12.10 \\
\hline $\mathrm{SiO}_{2}$ & - & 51.84 & 22.89 & 18.95 & 57.02 & 60.45 \\
\hline $\mathrm{Al}_{2} \mathrm{O}_{3}$ & 0.21 & 11.87 & 3.85 & 3.30 & 13.45 & 13.23 \\
\hline $\mathrm{Fe}_{2} \mathrm{O}_{3}$ & 0.25 & 4.85 & 2.09 & 1.65 & 4.09 & 4.71 \\
\hline $\mathrm{Na}_{2} \mathrm{O}$ & 0.05 & 0.75 & 0.08 & 0.03 & 1.11 & 0.96 \\
\hline $\mathrm{K}_{2} \mathrm{O}$ & 0.02 & 2.31 & 0.06 & 0.05 & 1.94 & 1.54 \\
\hline $\mathrm{MgO}$ & 0.30 & 1.17 & 1.03 & 0.76 & 0.85 & 1.06 \\
\hline $\mathrm{SO}{ }_{3}$ & 0.01 & 0.41 & 0.07 & 0.04 & 0.08 & 0.05 \\
\hline $1.0 . i^{*}$ & 43.80 & 16.00 & 30.66 & 32.90 & 5.10 & 4.40 \\
\hline Total & 99.24 & 98.13 & 97.75 & 97.60 & 99.54 & 98.50 \\
\hline
\end{tabular}

*loss on ignition at $950^{\circ} \mathrm{C}$, according to EN 196-2 Standard for cements.

As far as CW1 and CW2 are concerned, XRD data showed the presence of: calcium carbonate $\left(\mathrm{CaCO}_{3}\right)$ and quartz $\left(\mathrm{SiO}_{2}\right)$ as principal mineralogical phases; quartz, alumina $\left(\mathrm{Al}_{2} \mathrm{O}_{3}\right)$, and calcium aluminium iron oxide $\left(\mathrm{CaO} \cdot \mathrm{Al}_{2} \mathrm{O}_{3} 2 \mathrm{Fe}_{2} \mathrm{O}_{3}\right)$ were the main mineralogical phases of MW1 and MW2. 
Commercial natural gypsum, containing about $80 \%$ of $\mathrm{CaSO}_{4} \cdot 2 \mathrm{H}_{2} \mathrm{O}$ by mass, was used for portland cement preparations in the laboratory, which were submitted to hydration tests.

Mixtures formulation. Four ternary mixtures (Mix1, Mix2, Mix3, and Mix4), based on L, CW, and MW, were studied. A binary mixture (Mix0), composed by $\mathrm{L}$ and $\mathrm{C}$, was used as a reference. The formulation of the investigated mixtures is displayed in Table 2. It was selected judiciously in order to obtain the similar hydraulic modulus and silica modulus, namely $\mathrm{CaO} /\left(\mathrm{SiO}_{2}+\mathrm{Al}_{2} \mathrm{O}_{3}+\mathrm{Fe}_{2} \mathrm{O}_{3}\right)$ and $\mathrm{SiO}_{2} /\left(\mathrm{Al}_{2} \mathrm{O}_{3}+\mathrm{Fe}_{2} \mathrm{O}_{3}\right)$ mass ratios, respectively.

Table 2. Composition of raw mixtures, mass \%

\begin{tabular}{|c|c|c|c|c|c|c|}
\hline & L & C & CW1 & CW2 & MW1 & MW2 \\
\hline Mix0 & 72.6 & 27.4 & - & - & - & - \\
\hline Mix1 & 50.0 & - & 39.6 & - & 10.4 & - \\
\hline Mix2 & 48.8 & - & 42.9 & - & - & 8.3 \\
\hline Mix3 & 32.1 & - & - & 62.1 & 5.8 & - \\
\hline Mix4 & 30.5 & - & - & 65.1 & - & 4.4 \\
\hline
\end{tabular}

These compositional parameters, hydraulic modulus and silica modulus, control the performance of portland cement. They were respectively selected equal to 2.2 and 2.9. Such values are frequently adopted in cement manufacturing.

\section{Laboratory testing procedures}

In order to assess the burnability, the five mixtures were submitted to several thermal treatments carried out in a laboratory electric-oven at various synthesis temperatures. It should be pointed out that laboratory burnability tests are meaningful only for comparative purposes; in this study, in fact, the C\&DW behavior is compared with that of materials typically used for portland cement manufacture. Furthermore, laboratory data can be different from those achieved in a production-grade industrial kiln, because burnability depends not only on the characteristics of the raw materials but also on parameters such as kiln atmosphere, movement of material, and rate of heat transfer inside the clinkering zone. The burnability of a raw mixture for portland cement manufacture can be defined as the ease with which calcium oxide derived from limestone calcination reacts in the kiln with silicon, aluminium, and iron oxides contained in the argillaceous materials to produce the clinker. According to a given heating cycle, burnability is evaluated by either the amount of unreacted calcium oxide (free lime) present after a fixed treatment duration, or by the burning time needed to reduce the free lime content to some specific minimum value [Taylor 1997]. The test adopted [Bernardo et al. 2007] in this investigation, for obtaining a burnability index (BI) for each raw materials mixture, was based on the following thermal treatment: (a) first step at $105^{\circ} \mathrm{C}$ for $120 \mathrm{~min}$; (b) second step at $600^{\circ} \mathrm{C}$ for $30 \mathrm{~min}$; and, (c) third step at the final temperature $\left(1350^{\circ}, 1400^{\circ}, 1450^{\circ}\right.$ or $\left.1500^{\circ} \mathrm{C}\right)$ for $15 \mathrm{~min}$. The burnability index is given by the formula:

$$
\mathrm{BI}=3.73 \times(\mathrm{A}+\mathrm{B}+2 \mathrm{C}+3 \mathrm{D}) /(\mathrm{A}-\mathrm{D})^{1 / 4}
$$

where $\mathrm{A}, \mathrm{B}, \mathrm{C}, \mathrm{D}$ are the free lime contents in the product burnt at $1350^{\circ}, 1400^{\circ}, 1450^{\circ}$ and $1500^{\circ} \mathrm{C}$, respectively; a low-BI value reveals good burnability; furthermore, BI values lower than 60 indicate a very satisfactory behaviour.

The free lime $(\mathrm{CaO})$ concentration in portland clinkers was measured by the Franke method [Shelb and Ludwig 1978], based on lime extraction with organic solvents, followed by chemical titration. BI values (a) lower than 60, (b) 60-80, (c) 80-100, (d) 100-120, (e) 120-140, (f) 140-160, or (g) higher than 160 indicate, respectively, a very easy, easy, normal, slightly difficult, difficult, very difficult, extremely 
difficult burning of the raw materials in the mixture. The clinkers obtained at $1500^{\circ} \mathrm{C}$ from all five mixtures (CM0, CM1, CM2, CM3, and CM4), were characterized by XRD analysis, and, also, mixed with $5 \%$ natural gypsum and ground in laboratory mill to pass the $90 \mu \mathrm{m}$-sieve in order to prepare these five portland cements, respectively indicated as CEM0, CEM1, CEM2, CEM3, and CEM4. These cements were mixed with water and hydrated (water/cement ratio, 0.5 by mass) for $2,7,14$, and 28 days. The paste samples, shaped as cylindrical discs $(15 \mathrm{~mm}$ high and $30 \mathrm{~mm}$ in diameter), were placed in polyethylene bags inside a thermostatic bath at $20^{\circ} \mathrm{C}$. At the end of each aging period, they were pulverized and submitted to differential thermal-thermogravimetric (DTA-TG) analysis (Netzsch Tasc 414/3 apparatus, heating rate $10^{\circ} \mathrm{C} / \mathrm{min}$ ). A treatment with acetone (to stop hydration) and diethyl ether (to remove water), followed by storing the samples in a desiccator over silica gel-soda lime (to ensure protection against $\mathrm{H}_{2} \mathrm{O}$ and $\mathrm{CO}_{2}$ ), was performed.

\section{RESULTS AND DISCUSSION}

In Table 2, it is indicated that saving of natural raw materials is comprised between 50 and $70 \%$. Compared to Mix0, the other mixtures did not contain clay and had only lower amounts of limestone. Furthermore, Mix4 allowed the highest reduction of limestone requirement $(-58 \%)$.

The potential phase composition of the clinkers generated at $1500^{\circ} \mathrm{C}$, in terms of their four major constituents $\left(3 \mathrm{CaO} \cdot \mathrm{SiO}_{2}, 2 \mathrm{CaO} \cdot \mathrm{SiO}_{2}, 3 \mathrm{CaO} \cdot \mathrm{Al}_{2} \mathrm{O}_{3}, 4 \mathrm{CaO} \cdot \mathrm{Al}_{2} \mathrm{O}_{3} \cdot \mathrm{Fe}_{2} \mathrm{O}_{3}\right)$, was calculated from their elemental analysis according to Bogue's equations [Taylor 1997], see Table 3.

Table 3. Potential phase composition of OPC clinkers synthesized at $1500^{\circ} \mathrm{C}$, mass $\%$

\begin{tabular}{|c|c|c|c|c|}
\hline & $3 \mathrm{CaO} \cdot \mathrm{SiO}_{2}$ & $2 \mathrm{CaO} \cdot \mathrm{SiO}_{2}$ & $3 \mathrm{CaO} \cdot \mathrm{Al}_{2} \mathrm{O}_{3}$ & $4 \mathrm{CaO} \cdot \mathrm{Al}_{2} \mathrm{O}_{3} \cdot \mathrm{Fe}_{2} \mathrm{O}_{3}$ \\
\hline $\mathrm{CM} 0$ & 60.05 & 18.53 & 10.14 & 7.19 \\
\hline $\mathrm{CM} 1$ & 62.31 & 17.96 & 8.60 & 6.33 \\
\hline $\mathrm{CM} 2$ & 65.62 & 15.03 & 7.85 & 6.50 \\
\hline $\mathrm{CM} 3$ & 63.22 & 20.56 & 8.53 & 6.45 \\
\hline $\mathrm{CM} 4$ & 65.15 & 19.04 & 8.10 & 6.54 \\
\hline
\end{tabular}

The similarity in the mineralogical composition is evident among these five clinkers.

Figure 1 shows the free lime concentration in the laboratory burnt products of the five mixtures, as a function of the final temperature reached at the end of the third step of each heating cycle. 


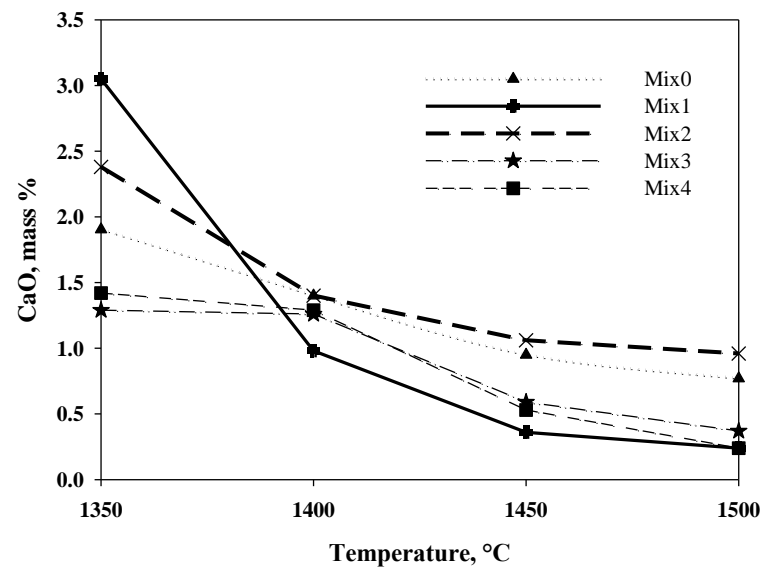

Figure 1. Free $\mathrm{CaO}$ concentration vs. final temperature of the burnability test

It is evident that free- $\mathrm{CaO}$ content decreases as temperature increases.

For example, Figure 2 shows the XRD patterns for CM0 and CM4 pair, burnt at $1500^{\circ} \mathrm{C}$.
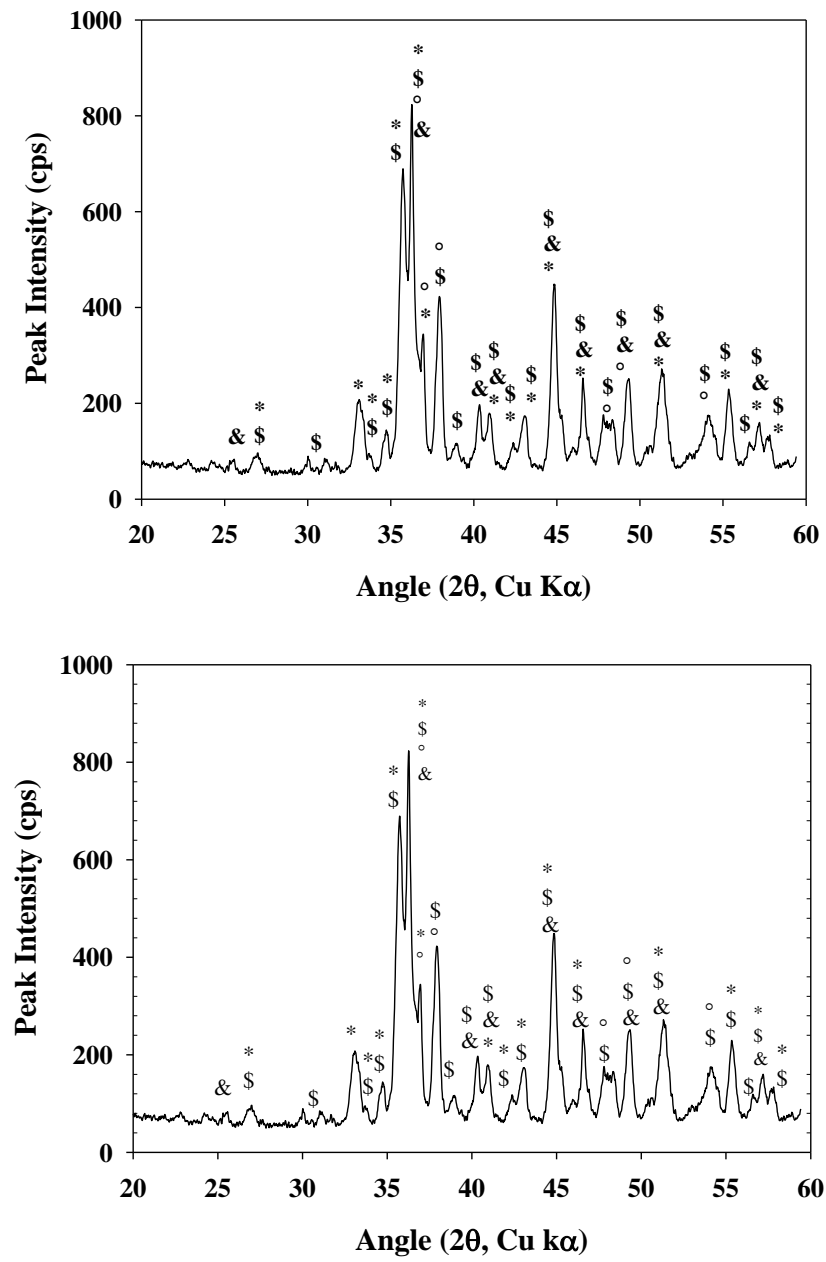

Figure 2. XRD patterns for CMO (top) and $\mathrm{CM} 4$ (bottom) clinkers $\left(*=3 \mathrm{CaO} \cdot \mathrm{SiO}_{2}\right.$, $\left.\$=2 \mathrm{CaO} \cdot \mathrm{SiO}_{2}, \&=3 \mathrm{CaO} \cdot \mathrm{Al}_{2} \mathrm{O}_{3},{ }^{\circ}=4 \mathrm{CaO} \cdot \mathrm{Al}_{2} \mathrm{O}_{3} \cdot \mathrm{Fe}_{2} \mathrm{O}_{3}\right)$ 
BI values for CM0, CM1, CM2, CM3, and CM4 were, respectively, 29.0, 15.8, 23.1, 19.6, and 14.2. Hence, all C\&DW based mixtures had a very satisfactory behaviour and gave a burnability index lower than that of the reference mixture, CM0.

When the five clinkers were compared on the basis of the XRD results, it was observed that their mineralogical composition was similar, in terms of the four major clinker constituents: $3 \mathrm{CaO} \cdot \mathrm{SiO}_{2}$ (AMCSD code 0017753), 2CaO $\cdot \mathrm{SiO}_{2}$ (AMCSD code 0012179), 3CaO $\cdot \mathrm{Al}_{2} \mathrm{O}_{3}$ (AMCSD code 0017746), and $4 \mathrm{CaO} \cdot \mathrm{Al}_{2} \mathrm{O}_{3} \cdot \mathrm{Fe}_{2} \mathrm{O}_{3}$ (AMCSD code 0003442 ).

The hydration behavior of the investigated cements was analogous in terms of development of the main hydration products detectable by means of DTA-TG analysis, namely calcium-silicate hydrate, ettringite, and calcium hydroxide (which underwent a partial carbonation), through the following dehydration endothermal peaks: $97^{\circ} \pm 11^{\circ} \mathrm{C}, 146^{\circ} \pm 18^{\circ} \mathrm{C}$, and $496^{\circ} \pm 26^{\circ} \mathrm{C}$, respectively [Taylor 1997]. As an example, Figure 3 reports the DTA-TG results for OPC cements cured up to 28 days and originated by the clinkers derived from CEM0, CEM1, and CEM2.
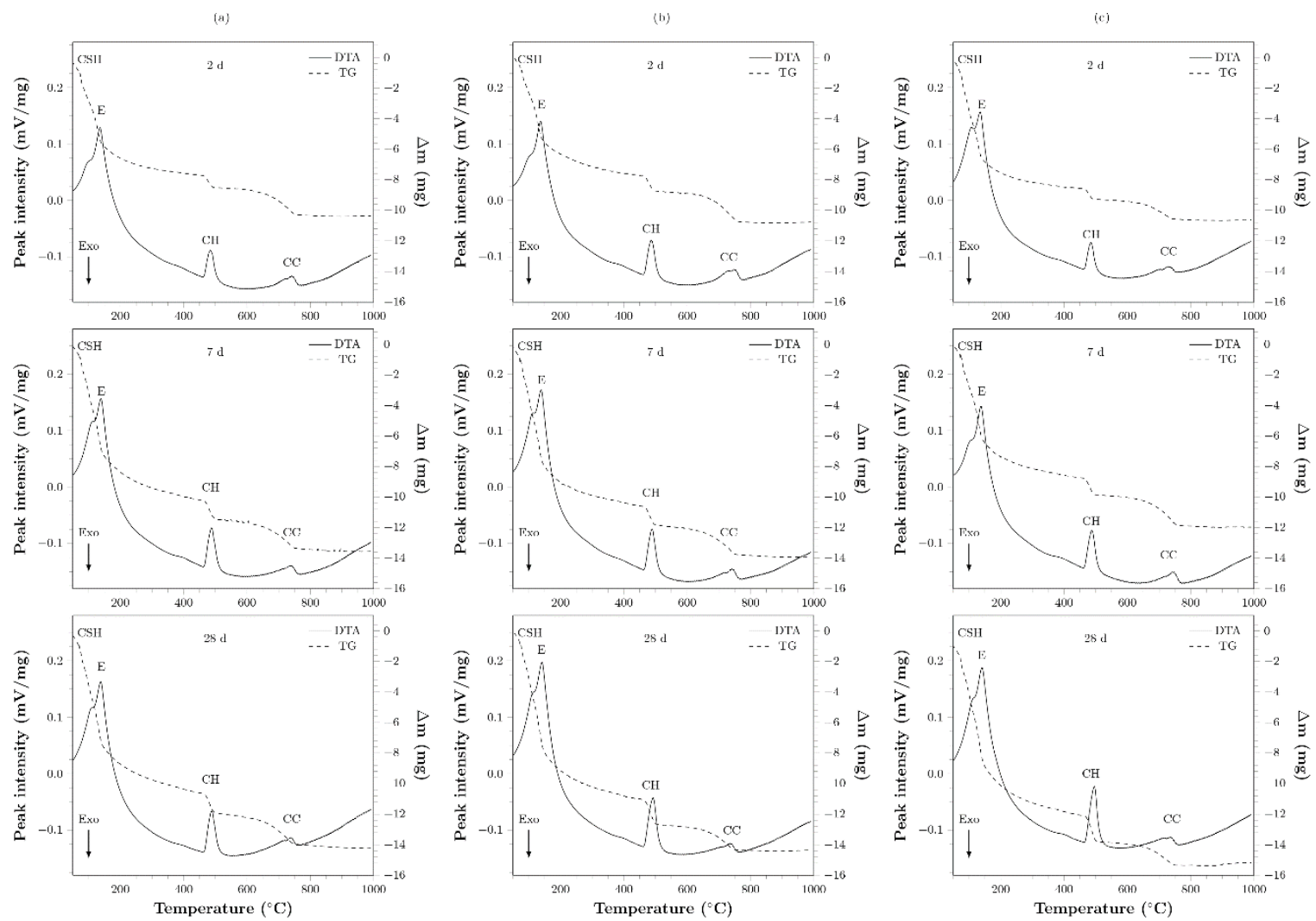

Figure 3. DTA-TG thermograms for CEMO (a), CEM1 (b) and CEM2 (c) pastes cured for 2, 7 and 28 days $(\mathrm{CSH}=$ calcium silicate hydrate, $\mathrm{E}=$ ettringite, $\mathrm{CH}=$ calcium hydroxide, $\mathrm{CC}=$ calcium carbonate)

\section{CONCLUSION}

Significant amounts of construction and demolition waste (C\&DW), namely concrete waste $(\mathrm{CW})$ and masonry waste (MW), can be utilized as partial or total substitutes for natural raw materials (i.e., limestone and clay, respectively) as components of the kiln-feed in the cement industry, thus giving a significant contribution to the sustainable development.

Keeping constant both the hydraulic modulus and silica modulus [namely the 
$\mathrm{CaO} /\left(\mathrm{SiO}_{2}+\mathrm{Al}_{2} \mathrm{O}_{3}+\mathrm{Fe}_{2} \mathrm{O}_{3}\right)$ and the $\mathrm{SiO}_{2} /\left(\mathrm{Al}_{2} \mathrm{O}_{3}+\mathrm{Fe}_{2} \mathrm{O}_{3}\right)$ mass ratios] for each raw mixture, $\mathrm{MW}$ enabled the total clay replacement, while $\mathrm{CW}$ allowed a limestone replacement ranging from 31 to $58 \%$.

The XRD and DTA-TG results of the present investigation, aimed at exploring the behaviour of four ternary OPC clinker-generating raw mixtures composed of clay or MW plus limestone and CW, demonstrated that significant differences were not associated with the kind of lime, silica, and alumina sources found in C\&DW. A binary mixture, based on limestone and clay, was used as a reference term. The mineralogical composition of the synthetic clinkers obtained at $1500^{\circ} \mathrm{C}$ was similar. Strong analogies were also observed with regard to the development of hydration products generated by the relevant cements.

\section{REFERENCES}

Bernardo, G. Marroccoli, M., Nobili, M., Telesca, A., and Valenti, G.L. (2007). "The use of oil wellderived drilling waste and electric arc furnace slag as alternative raw materials in clinker production." Resources, Conservation and Recycling, 52, 95-102.

Bijen, J. (1996). "Benefits of slag and fly ash." Construction and Building Materials, 10(5), 309-14.

Bilodeau, A., and Malhotra, V.M. (2000). "High-volume fly ash system: concrete solution for sustainable development." ACI Materials Journal, 97(1), 41-8.

CEMBUREAU (The European Cement Association), (2015) “Activity report 2014." $\mathrm{N}^{\circ}$ Editeur: D/2015/5457/May.

Corinaldesi, V., and Moriconi, G. (2009). "Behaviour of cementitious mortars containing different kinds of recycled aggregate". Construction and Building Materials, 23, 289-94.

Dahlbo, H., Bach, J., Lahtinen, K., Jouttijarvi, T., Suoheimo, P., Mattila, T., Sironen, S., Myllymaa, T., and Saramaki. K. (2015). "Construction and demolition waste management - a holistic evaluation of environmental performance." Journal of Cleaner Production, 107, 333-341.

Eurostat statistics explained. Waste statistics. <http://ec.europa.eu/eurostat/statisticsexplained/index.php/Waste_statistics> (2012).

Gartner, H., and Hirao, H. (2015). "A review of alternative approaches to the reduction of CO2 emissions associated with the manufacture of the binder phase in concrete." Cement and Concrete Research, 78, 126-142.

Gastaldi, D., Canonico, F., Capelli, L., Buzzi, L., Boccaleri, E., and Irico, S. (2015). “An investigation on the recycling of hydrated cement from concrete demolition waste." Cement \& Concrete Composites, $61,29-35$.

Joris Schoon, Klaartje De Buysser, Isabel Van Driessche, Nele De Belie, Fines extracted from recycled concrete as alternative raw material for Portland cement clinker production. Cement \& Concrete Composites 58 (2015) 70-80.

Kääntee, U., Zevenhoven, R., Backman, R., and Hupa, M. (2004). "Cement manufacturing using alternative fuels and the advantages of process modelling". Fuel Processing Technology, 85, 293-301.

MacGregor, M. (1994). "Emerging technologies for utilizing waste in cement production." World Cement, 25, 49-51.

Mahmud, H.B., Majuar, E., Zain, M.F.M., and Hamid, N.B.A.A. (2004). "Mechanical properties and durability of high strength concrete containing rice husk ash." Proceedings of eighth CANMET/ACI international conference on fly ash, silica fume, slag and natural pozzolans in concrete, ACI SP-221, 751-766. 
Marroccoli, M., Pace, M.L., Telesca, A., Valenti, G.L., and Montagnaro, F. (2010). "Utilization of coal combustion ashes for the synthesis of ordinary and special cements." Combustion Science and Technology, 82, 588-99.

Mokrzycki, E., and Uliasz-Bochenczyk, A. (2003). "Alternative fuels for the cement industry." Applied Energy, 74, 95-100.

Ramezanianpour, A.A., and Pourkhorshidi, A.R. (2004). "Durability of concretes containing supplementary cementing materials under hot and aggressive environment." Proceedings of eighth CANMET/ACI international conference on fly ash, silica fume, slag and natural pozzolans in concrete, ACI SP-221, 633-46.

Sano, S., Ichikawa, M., Nakamura, T., Fukuhara, Y., Matsuto, T., and Tanaka, N. (2002). "Utilization of municipal waste incinerator ash for cement production and carbon dioxide reduction by ashwashing technology, Proceedings of the Annual Conference of The Japan Society of Waste Management Experts, 23, 168-170.

Shelb, F.A., and Ludwig, U. (1978). "Investigations relating to the determination of calcium hydroxide by the Franke method." Zement-Kalk-Gips, 12, 510-515.

Silva, R.V., de Brito, J., and Dhir, R.K. (2014). "Properties and composition of recycled aggregates from construction and demolition waste suitable for concrete production." Construction and Building Materials, 65, 201-217.

Taylor, H.F.W. (1997). Cement chemistry. $2^{\text {nd }}$ Ed. (London), Thomas Telford.

Telesca, A., Calabrese, D., Marroccoli, M., Tomasulo, M., Valenti, G.L., Duelli (Varela), G., and Montagnaro, F. (2014). "Spent limestone sorbent from calcium looping cycle as a raw material for the cement industry." Fuel, 118, 202-205.

Telesca, A., Marroccoli, M., Tomasulo, M., Valenti, G.L., Dieter, H., and Montagnaro. F. (2015). "Calcium Looping Spent Sorbent as a Limestone Replacement in the Manufacture of Portland and Calcium Sulfoaluminate Cements." Environmental Science and Technology, 49, 6865-6871.

Trezza, M.A., and Scian, A.N. (2000). "Burning wastes as an industrial resource. Their effect on Portland cement clinker." Cement and Concrete Research, 30, 137-44.

Vieira, C.S., and Pereira, P.R (2015). "Use of recycled construction and demolition materials in geotechnical applications: A review." Resources, Conservation and Recycling, 103, 192-204. 